\title{
MENGGALI POTENSI, MEMOTIVASI DAN MENGARAHKAN GENERASI MUDA MENYONGSONG DUNIA KERJA PADA PKBM CIPTA TUNAS KARYA CIPONDOH KOTA TANGERANG
}

\author{
${ }^{1}$ Suwanto, ${ }^{2}$ Priehadi Dhasa Eka, ${ }^{3}$ Randhy Agusentoso, \\ ${ }^{4}$ Angga Juanda, ${ }^{5}$ Prasetyo Kurniawan \\ Dosen Fakultas Ekonomi Universitas Pamulang \\ Email : 1 dosen01813@unpam.ac.id
}

\begin{abstract}
ABSTRAK
Siswa PKBM Cipta Tunas Karya selain bisa langsung bekerja juga bisa melanjutkan ke jenjang pendidikan yang lebih tinggi yaitu perguruan tinggi namun memilih jurusan di perguruan tinggi tentunya menyesuaikan dengan minat dan kemampuan para anggota. Permasalahan yang sering terjadi adalah kurangnya pengetahuan para siswa tentang rencana kedepan sehingga banyak siswa PKBM yang justru menjadi pengangguran, hal tersebut karena kurangnya pengetahuan tentang persiapan memasuki dunia kerja serta jika ingin kuliah kurangnya pengetahuan tentang jurusan yang akan diambil dan bagaimana memilih perguruan tinggi yang baik dan benar. Untuk menghadapi permasalahan tersebut perlu diberikan pengarahan kepada para anggota tentang persiapan memasuki dunia kerja atau kuliah.

Metode pengabdian yang dilakukan adalah metode ceramah sebanyak dua kali pertemuan dengan lima narasumber yang berbeda. Pertemuan pertama materi tentang bagaimana Mimpi dan Cita cita , Persiapan Memasuki Dunia Kerja, Biodata diri dan Surat Lamaran, Wawancara Lamaran Kerja , Mengenal Tipe Soal Psikotes serta cara memilih jurusan dan perguruan tinggi yang benar. Pertemuan kedua dengan melakukan praktek dari materi yang telah di berikan.

Dari kuesioner yang disebar memberikan hasil bahwa para siswa merasa puas dengan materi yang diberikan dan berharap menjadi agenda rutin di PKBM Cipta Tunas Karya sebelum para anggota menyelesaikan pendidikan.
\end{abstract}

\section{Kata Kunci : Cita Cita, Dunia Kerja, Surat Lamaran, Wawancara, Psikotes}

\section{PENDAHULUAN}

PKBM Cipta Tunas Karya berperan positif dalam pertumbuhan ekonomi daerah, peran ini dapat dilacak dari tiga hal yaitu preferensi masyarakat, kapasitas bagi siswa PKBM Cipta Tunas Karya. dimulai dari berpendidikan SMP dan SMA yang tidak lulus Sekolah, dan kemampuan siswa PKBM Cipta Tunas Karya dalam mencetak siswa yang berkualitas dalam paket B dan paket C. Animo masyarakat terhadap PKBM Cipta Tunas Karya berkaitan dengan perkembangan siswa sangat baik.

PKBM Cipta Tunas Karya adalah sekolah kerjar paket yang beralamtkan Jl. Ki Hajar Dewantara RT 03/04 Kel Gondrong Kec Cipondoh kota Tangerang. 
PKBM Cipta Tunas Karya juga menciptakan kompetensi keahlian tersebut masuk dalam jurusan bisnis dan manajemen, yaitu kompetensi keahlian yang memberi bekal pengetahuan, keterampilan dan sikap. Kesiapan siswa PKBM Cipta Tunas Karya dalam memasuki dunia kerja juga dengan melakukan praktek kerja industri yang sebagian besar dilaksanakan di kota Tangerang Banten.merupakan kota industri, sehingga memudahkan para bagi siswa PKBM Cipta Tunas Karya terutama berpendidikan paket $\mathrm{C}$ atau setara dengan SMA/SMK/ untuk dalam mencari tempat praktek industri, praktek kerja tersebut dilaksanakan selama lebih kurang 1 semester (6 bulan). Gambar yang menunjukan siswa PKBM Cipta Tunas Karya masih terlihat kurang mendapatkan materi tentang persiapan memasuki dunia kerja atau kuliah, dimana para anggota hanya mendapatkan materi tentang bagaimana cara membuat surat lamaran yang dipelajari para anggota pada mata pelajaran Bahasa Indonesia, namun belum diberikan pembekalan tentang apa yang akan dilakukan para anggota kedepan setelah tamat karang taruna, semisal para anggota ingin bekerja di perusahaan, belum diberikan pembekalan tentang bagaimana cara mencari atau mendapatkan lowongan pekerjaan dengan cepat, bagaimana membuat surat lamaran atau daftar riwayat hidup yang baik, serta bagaimana teknik wawancara kerja yang baik. Jika orang tua para siswa mampu secara keuangan, kemudian para anggota ingin melanjutkan ke perguruan tinggi, masih kurangnya pengetahuan para anggota tentang memilih perguruan tinggi yang baik dan benar juga jurusan yang dipilih, dimana para i siswa PKBM Cipta Tunas Karya yang berpendidikan paket $C$ atau setara dengan SMA/SMK/ setelah masuk perguruan tinggi tapi tidak memilih melanjutkan ke jurusan sesuai pendidikan sebelumnya juga namun memilih jurusan lain. Adapun tujuan dari materi pembekalan memasuki dunia kerja atau kuliah ini adalah memberikan pembekalan dan pemahaman kepada para anggota tentang bagaimana cara menentukan pilihan setelah tamat dari PKBM Cipta Tunas Karya , apakah akan bekerja atau melanjutkan pendidikan keperguruan tinggi .

\section{METODE PELAKSANAAN KEGIATAN}

Pembinaan dengan hasil sebagai berikut:

1. Tim PKM yang merupakan dosen pada program studi Manajemen Universitas Pamulang turun untuk melaksanakan kegiatan pengabdian kepada masyarakat ini, tim PKM telah terlebih dahulu melakukan survey atau pengamatan pendahuluan dimana kegiatan survei ini dilaksanakan pada tanggal 07 Juli 2018. Survei yang dilakukan oleh tim PKM tersebut meliputi hal-hal sebagai berikut:

2. Silaturahmi dengan pihak PKBM dalam hal ini diwakili oleh PKBM Cipta Tunas Karya Bapak Kusuma Wijaya, S.Pd.,M.Pd. Pada kesempatan itu tim PKM mendengarkan keluhan-keluhan atau masukan bimbingan apa yang diinginkan dan dibutuhkan para selama ini. 
3. Sebelumnya tim PKM juga melakukan komunikasi dengan beberapa alumni Survey tempat/lokasi pelaksanaan pengabdian kepada masyarakat yang akan diadakan oleh team PKM sesuai tema PKM yaitu; Menggali Potensi, Memotivasi dan Mengarahkan Generasi Muda Menyongsong Dunia Kerja. dimana menyatakan bahwa selama karang taruna sampai dengan selesai, tidak

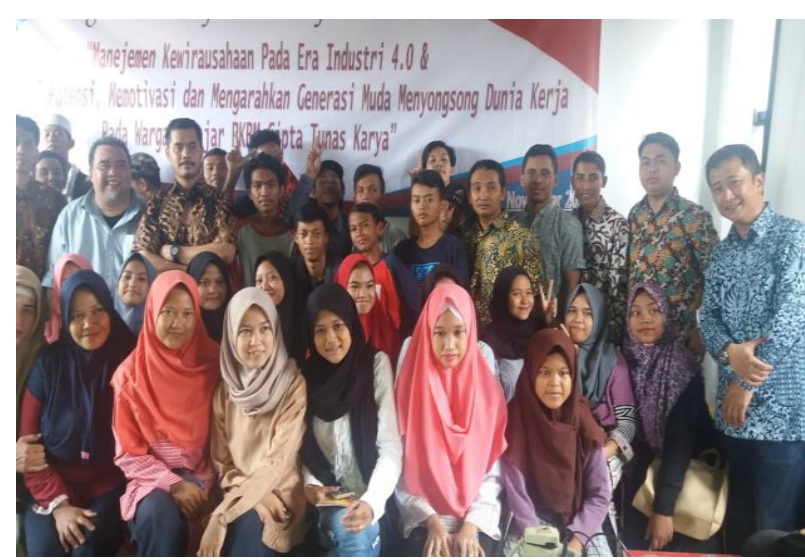
mendapatkan pembekalan untuk memasuki dunia kerja atau kuliah, sehingga alumni mengalami sedikit kendala sewaktu sudah selesai karang taruna, seperti bagaimana memilih perguruan tinggi yang baik dan benar, bagaimana teknik wawancara yang baik serta bagaimana melihat lowongan lowongan kerja yang ada.

4. Seluruh tim PKM menyiapkan bahan dan materi yang akan disampaikan pada tahap pelaksanaan, dimana seluruh tim PKM yang terdiri dari 5 orang yaitu 5 dosen dan merupakan narasumber dari kegiatan pengabdian kepada masyarakat dengan tema pembinaan sasaran anggota karang taruna. Tim PKM menyepakati untuk membagi materi menjadi dua kelompok yaitu pembekalan memasuki dunia kerja dan kuliah serta beberapa materi penunjang lainnya. Tim PKM sepakat untuk mempersiapkan materi presentasi yang dibagi menjadi 5 dengan materi pengantar Mimpi dan Cita Cita, persiapan menghadapi dunia kerja, membuat Surat Lamaran Kerja menyusun Bio Data, materi menghadapi Wawancara dan materi persiapan menghadapi Soal Psykotes yang nantinya akan disampaikan pada pertemuan pertama,kemudian pada pertemuan kedua pelatihan dengan materi praktek serta teori .

5. Menyepakati penentuan jadwal pembinaan dengan para siswa PKBM Cipta Tunas Karya dan Universitas Pamulang mengingat untuk pelatihan membutuhkan fasilitas itu sendiri dan semua fasilitas yang tersedia oleh Universitas Pamulang

6. Seluruh tim PKM menyiapkan bahan dan materi yang akan disampaikan pada tahap pelaksanaan, dimana seluruh tim PKM yang terdiri dari 5 orang yaitu 5 dosen dan merupakan narasumber dari kegiatan pengabdian kepada masyarakat dengan tema pembinaan sasaran anggota karang taruna. Tim PKM menyepakati untuk membagi materi menjadi dua kelompok yaitu pembekalan memasuki dunia kerja dan kuliah serta beberapa materi penunjang lainnya. Tim PKM sepakat untuk mempersiapkan materi presentasi yang dibagi menjadi 5 dengan materi pengantar Mimpi dan Cita Cita, persiapan menghadapi dunia kerja, membuat Surat Lamaran Kerja menyusun Bio Data, materi menghadapi Wawancara dan materi persiapan menghadapi Soal Psykotes yang nantinya 
akan disampaikan pada pertemuan pertama,kemudian pada pertemuan kedua pelatihan dengan materi praktek serta teori .

7. Menyepakati penentuan jadwal pembinaan dengan para siswa PKBM Cipta Tunas Karya dan Universitas Pamulang mengingat untuk pelatihan membutuhkan fasilitas itu sendiri dan semua fasilitas yang tersedia oleh Universitas Pamulang, dan karena jadwal belajar para siswa PKBM Cipta Tunas Karya cipondoh yang hanya belajar sampai dengan hari Jumat, maka disepakati untuk melaksanakan pengabdian pada hari Sabtu dengan tetap didampingi oleh pihak tokoh masyarakat dan lingkungan setempat.

8. Tim PKM menyerahkan surat izin pelaksanaan kegiatan pengabdian kepada ketua PKBM Cipta Tunas Karya cipondoh yang dikeluarkan secara resmi oleh Universitas Pamulang dan juga menyerahkan proposal pengadaan kegiatan pembinaan yang ditujukan bagi pihak pimpinan dalam hal ini Ketua. Surat izin dan laporan ini merupakan syarat dari pelaksanaan kegiatan pengabdian kepada masyarakat.

\section{HASIL DAN PEMBAHASAN}

Pelaksanaan Pengabdian Kepada Masyarakat dengan Pembinaan Sasaran pada siswa PKBM Cipta Tunas Karya ini tema tentang pembinaan Pembekalan Memasuki Dunia Kerja Atau Kuliah. Pembinaan tersebut terdiri dari materi pokok yang disampaikan oleh Tim PKM yaitu Pembekalan Memasuki Dunia Kampus dan Pembekalan Memasuki Dunia Kerja yang disampaikan pada pertemuan pertama tanggal 20 Juli 2019 dimana pada pembekalan memasuki dunia kampus dijelaskan tentang kenapa kuliah itu penting, jika kuliah masih memungkinkan untuk bisa sambil bekerja atau berwirausaha untuk memanfaatkan waktu yang ada dan melakukan time management, dalam materi ini juga disampaikan bagaimana memilih perguruan tinggi yang baik dan benar serta memilih jurusan yang benar. Materi kedua pada pertemuan pertama disampaikan tentang bagaimana jika setelah selesai karang taruna ingin langsung bekerja, apa saja yang harus dipersiapkan untuk bekal menghadapi dunia kerja, seperti teknik wawancara yang benar, bagaimana mencari dan mendapatkan lowongan kerja serta jika memilih ingin berwirausaha, apa saja yang harus disiapkan. Pelaksanaan pengabdian pada pertemuan kedua berisi tentang praktek atas materi yang telah di pelajari kupas tuntas terkait hal hal sebagai berikut :

1. Isu terkini terkait jumlah lulusan dan pengangguran serta menangkap peluang

2. Menentukan tujuan dan atau cita cita usai lulusan smk sesuai dengan potensi yang dimiliki.

3. Mencari prospek sebagai tujuan tempat bekerja usai lulus SMK

4. Menyiapkan berkas berkas dokumen sebelum memasuki dunia kerja

5. Mengenal tipe tipe soal psikotest \& memecahkannya

6. Teknik menghadapi wawancara kerja

7. Memilih kampus yang tepat sesuai dengan situasi dan kondisi pribadi siswa 


\section{KESIMPULAN DAN SARAN}

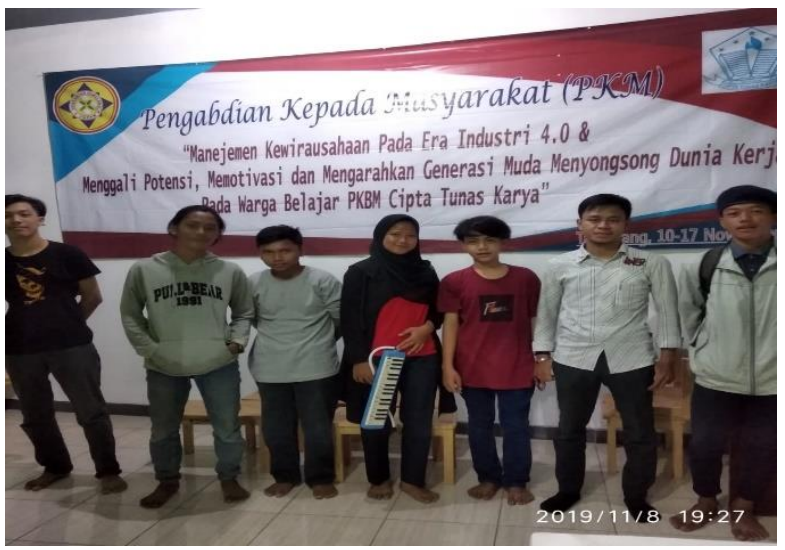

Pelaksanaan kegiatan ini diharapkan bisa menjadi agenda rutin bagi pihak karang taruna agar para anggota mendapatkan pembekalan setelah siswa PKBM menjelang tamat sekolah, karena keterbatasan waktu dan tempat, belum semua para mendapatkan pembekalan tersebut, diharapkan kedepannya kegiatan ini bisa diberikan kepada seluruh para siswa terutamanya para siswa

PKBM cipta tunas karya yang masih di jenjang pendidikan sekolah serta usia memasuki dunia kerja.

\section{DAFTAR PUSTAKA}

Salim segaf Al zufri,MA. (2010), Tentang Pedoman Pendidikan. Di Jakarta Sunarsi, D., \& Asmalah, L. (2018). Pelatihan Manajemen Pengembangan Diri Bagi Penerima Beasiswa RZIS UGM Dan Dompet Shalahuddin Jogjakarta. Jurnal Pengabdian Dharma Laksana, 1(1). Undang - Undang Nomor 40 Tahun 2009.Tentang Kepemudaan

Suwanto, S. (2019). Pengaruh Disiplin Kerja Dan Motivasi Kerja Terhadap Kinerja Karyawan Pada Rumah Sakit Umum Tangerang Selatan. JENIUS, 3(1), 16-23.

Suwanto, S. (2019). Pengaruh Gaya Kepemimpinan Dan Lingkungan Kerja Terhadap Kinerja Karyawan Unit Telesales Pada PT BFI Finance Indonesia TBK. Jurnal Ekonomi Efektif, 1(2) 